\title{
STRATEGI PENDEKATAN PEMBELAJARAN DALAM PERSFEKTIF AL-QUR'AN
}

\author{
Asep Supriatna ${ }^{1}, H_{e r d i a n} K_{e r t a y a s a}{ }^{2}$, Alfyan Syach ${ }^{3}$, Chika Gianistika ${ }^{4 *}$ \\ 1,2,3,4 (Prodi Pendidikan Guru Madrasah Ibtidaiyah, STIT RakeyanSantangKarawang) \\ * Corresponding Author. E-mail: aasepstea@gmail.com.
}

Receive: 04/03/2021

Accepted: 08/03/2021

Published: 28/03/2021

\begin{abstract}
Abstrak
Strategi Pendekatan dalam pembelajaran memiliki pengaruh penting dalam kegiatan belajar mengajar. Semakin banyak pendekatan yang digunakan, pembelajaran yang dilakukan akan semakin menyenangkan, melahirkan nalar kritis peserta didik dan kreatifitas guru. Beberapa ayat al-Quran memberikan gambaran tentang pendekatan-pendekatan dalam pembelajaran pendidikan Islam. Hal ini dimaksudkan agar para pendidik yang mengajarkan pendidikan Islam memiliki sikap terbuka dalam mengembangkan berbagai macam pendekatan pembelajaran. Sehingga, pembelajaran yang dilakukan menjadi tidak membosankan. Jenis penelitian yang digunakan peneliti adalah library research atau penelitian kepustakaan, yang dimaksud penelitian kepustakaan adalah penelitian yang menjadikan data-data kepustakaan sebagai teori untuk dikaji dan ditelaah dalam memperoleh hipotesa atau konsepsi untuk mendapatkan hasil yang objektif. Dalam pengambilan data penulis mengambil dari beberapa sumber diantaranya: al-Quran, Hadis, Buku-buku, Kitab-kitab dan referensi-referensi yang menunjang penelitian ini seperti pendapat para Ulama dan para pakar pendidikan Islam. Hasil penelitian ini menunjukkan Strategi Pendekatan Pembelajaran menurut alQuran yaitu; 1) pendekatan hikmah, 2) pendekatan nasihat atau pengajaran yang baik, 3) pendekatan Diskusi/jidal, 4) pendekatan keteladanan, 5) pendekatan ceramah, 6) pendekatan pengalaman praktis (trial and error), yaitu melalui percobaan dan pengamatan.
\end{abstract}

Kata Kunci: Strategi, Pendekatan Pembelajaran Al-Quran, Pendidikan Islam

Abstract

Strategy The approach to learning has an important influence in teaching and learning activities. The more approaches used, the more enjoyable the learning will be, giving birth to students' critical reasoning and teacher creativity. Several verses of the Koran provide an overview of the approaches to learning Islamic education. This is so that educators who teach Islamic education have an open attitude in developing various kinds of learning approaches. So, the learning that is carried out is not boring. The type of research used by researchers is library research or library research, which means library research is research that uses library data as a theory to be studied and analyzed in obtaining hypotheses or conceptions to obtain objective results. In collecting data, the authors took from several sources including: the Koran, Hadith, books, books and references that support this research, such as the opinions of scholars and experts in Islamic education. The results of this study indicate the Learning Approach Strategy according to the Koran, namely; 1) wisdom approach, 2) good advice or teaching approach, 3) discussion / jidal approach, 4) exemplary approach, 5) lecture approach, 6) practical experience approach (trial and error), namely through experiment and observation.

Keywords: Strategy, Al-Quran Learning Approach, Islamic Education 


\section{Pendahuluan}

Pendidikan merupakan suatu proses pendewasaan pesertadidik melalui pembelajaran secara sadar dan terencana untuk secara aktif mengoptimalkanpotensi yang menyangkut tentang strategi pembelajaran selalu menjadi bahan yang menarik. barat dengan segala pernik peradaban pendidikannya bukan berarti harus ditolak mentah-mentah segala produknya oleh dunia pendidikan Islam. Pun, bukan berarti pula umat Islam menerima sepenuhnya. AlQuran dan Al-Hadis harus menjadi filter untuk menyaring itu semua, selagi konsepsi Strategi Pendekatan Pembelajaran dalam Al-Quran secara genuine masih terus digali dan dikaji.

Dalam tujuan penelitian ini akan dibahas strategi pendekatan pembelajaran dalam persfektif al-Quran dengan telaah studi pustaka deskriptif kualitatif, di mana dalam penelitian ini untuk mengkaji istilah strategi pendekatan pembalajaran ditelaah secara bahasa dan telaah pustaka, dengan pendekatan al-Quran, Hadis Nabi dan pendapat para Ulama dan pakar pendidikan Islam.

\section{Hasil dan Pembahasan}

Kata strategi baru berkembang pada abad ke-19th M terambil dari bahasa Perancis stratégie. Kata itu sendiri merupakan perkembangan kemudian dari bahasa Yunani stratēgia, yang dalam bahasa Inggris biasanya disepadankan dan diartikan dengan, generalship, keahlian militer, sebagai bentuk derivasi dari stratēgos dan stratagem (Kamus Oxford-dictionari online). Kamus Oxforddictionary, wakil dari kamus otoritatif berbahasa inggris membatasi pengertian kata strategy dengan definisi: 1) A plan of action designed to achieve a long-term or overall aim, rencana suatu aksi yang dirancang untuk mencapai tujuan jangka panjang atau tujuan secara keseluruhan dari aksi; 2) The art of planning and directing overall military operations and movements in a war or battle, Seni perencanaan dan pengarahan secara keseluruhan operasi militer dan gerakan dalam perang atau pertempuran.

Bahasa dan peradaban Indonesia menyerap dan membakukan kata tersebut menjadi strategi. Kamus Besar Bahasa Indonesia(http://kbbi.web.id/strategi), sebagai kamus yang paling otoritatif dijadikan rujukan ilmiah mendefinisikan kata strategi dalam empat pengertian, yaitu: 1) ilmu dan seni menggunakan semua sumber daya bangsa untuk melaksanakan kebijaksanaan tertentu dalam perang dan damai; 2) ilmu dan seni memimpin bala tentara untuk menghadapi musuh dalam perang, dalam kondisi yang menguntungkan; 3) rencana yang cermat mengenai kegiatan untuk mencapai sasaran khusus; 4) tempat yang baik menurut siasat perang. Peradaban Bahasa Arab yang juga sebagai Bahasa Resmi Al-Quran mengadopsi

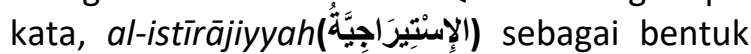
padanan kata strategi.

Kata al-istīrājiyyah dengan berbagai macam bentuk derivasinya tidak diketemukan satu kata-pun dalam al-Quran. Dilacak dalam tradisi Rasulullah Muhammad yang terangkum dalam kitab Hadis dan sirah (sejarah)-pun kata itu tidak diketemukan sama sekali. Kata alistīrājiyyah merupakan serapan kosa-kata baru dalam bahasa Arab. Kementerian Pendidikan dan IImu Pengetahuan Kerajaan Arab Saudi, Wijārat al-Tarbiyyah wa al-Talīm (2016), menerbitkan buku buku Pedoman Pendidikan dengan tema alistīrājiyyahTațīr Tadrīs al-Qurān al-Karīm fì Madāris Tahfiż al-Qurān al-Karīm ( استراتيجيات تطوير تدريس القرآن الكريم في مدارس تحفيظ القرآن الكريم الكران Buku itu menggunakan kata alistīrājiyyah, strategi,ketika mendedahkan strategi Pembelajaran. Strategi Pembelajaran, istīrājiyyah tadrīs (وإستراتيجية التدريس) menurut Kementerian tersebut adalah:

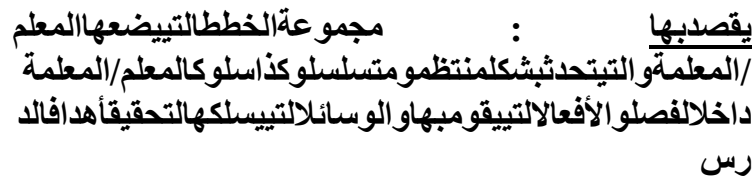

Pengertian dari kalimat di atas lebih memiliki kecenderungan strategi dimaknai sebagai suatu kumpulan langkah-langkah atau prosedur, metode dan teknik kegiatan 
pembelajaran yang harus dikerjakan guru dan siswa agar tujuan pembelajaran dapat dicapai secara efektif dan efisien.

Melacak term-term strategi atau langkah-langkah atau prosedur, metode dan teknik juga tidak diketemukan dalam al-Quran yang dapat menuntun membahas tema strategi pendekatan pembelajaran dalam alQuran. Penulis menemukan satu karya ilmiah dari Waseem Gul (2016, hlm. 156),seorang Performance Manager (Technical Support), dari Ericsson Communication Co. Ltd., Beijing, P. R. China. Melalui karyanya, "Strategy: Does the Concept Exist in Islamic Sources of Knowledge?," Gul menyatakan bahwa tidak mungkin atau mustahil bisa melacak konsepsi atau paradigma strategi dalam al-Quran. Sebagai mana yang terlihat dalam judulnya, strategi bukan merupakan konsep yang telah eksis dalam sumber hukum Islam, baik dari alQuran maupun hadis.

Merujuk penelusuran Gull, Abul Ala alMaududi dan M. Asad (1988) mensinonimkan terma strategi dalam al-Quran dengan kalimat: 1) makar, yang terdiri atas rangkaian huruf mim-kāf-rā ( (2) $)$; 2) kaida dari rangkaian kata kāf-yā-dāl (كي-د); khadaa, dari rangkaian kata khā dāl 'ayn (ع-د-خ). Kata makara dalam berbagai bentuk katanya ditemukan sebanyak 43 kata dalam beragam surat dan ayat dalam al-Quran, yaitu: (3:54), (3:54), (6:123), (6:123), (6:124), (7:123), (8:30), (8:30), (8:30), (10:21), $(12: 102), \quad(13: 42), \quad(14: 46), \quad(16: 26), \quad(16: 45)$, (16:127), (27:50), (27:50), (27:70), (35:10), (40:45), (71:22), (7:99), (7:99), (7:123), (10:21), $(10: 21), \quad(12: 31), \quad(13: 33), \quad(13: 42), \quad(14: 46)$, (14:46), (14:46), (27:50), (27:50), (27:51), (34:33), (35:10), (35:43), (35:43), (71:22), (3:54), (8:30). Contoh firman Allah itu, misalnya (3:54), adalah: "Orang-orang kafir itu membuat tipu daya, dan Allah membalas tipu daya mereka itu. dan Allah Sebaik-baik pembalas tipu daya." (QS. Ali Imran/3: 54).

Kata kaida dengan berbagai macam derivasinya ditemukan tersebar dalam 35 kata dengan akar kata kōf yō dōl, yaitu: (7:195), (11:55), (12:5), (12:76), (21:57), (77:39), (86:15), (86:16), (3:120), (4:76), (7:183), (8:18), $(12: 5), \quad(12: 28), \quad(12: 28), \quad(12: 33), \quad(12: 34)$, (12:50), (12:52), (20:60), (20:64), (20:69), (21:70), (22:15), (37:98), (40:25), (40:37), (52:42), (52:46), (68:45), (77:39), (86:15),
(86:16), (105:2), (52:42). Misalnya adalah (7:195), yaitu: "Apakah berhala-berhala mempunyai kaki yang dengan itu ia dapat berjalan, atau mempunyai tangan yang dengan itu ia dapat memegang dengan keras, atau mempunyai mata yang dengan itu ia dapat melihat, atau mempunyai telinga yang dengan itu ia dapat mendengar? Katakanlah: "Panggillah berhala-berhalamu yang kamu jadikan sekutu Allah, kemudian lakukanlah tipu daya (untuk mencelakakan)-ku. tanpa memberi tangguh (kepada-ku)". (QS. Al-Arāf/7: 195)."

Kata khadaa dalam berbagai bentuknya ditemukan dalam 5 ayat, yaitu: (2:9), (8:62), (2:9), (4:142), (4:142). Misalnya (2:9), yaitu:

"Mereka hendak menipu Allah dan orangorang yang beriman, Padahal mereka hanya menipu dirinya sendiri sedang mereka tidak sadar." (QS. Al-Baqarah/2: 9).

Berdasarkan pelacakan terma strategi pada tradisi rasulullah ditemukan pula terma Kata khadaa, yaitu pada Hadis:

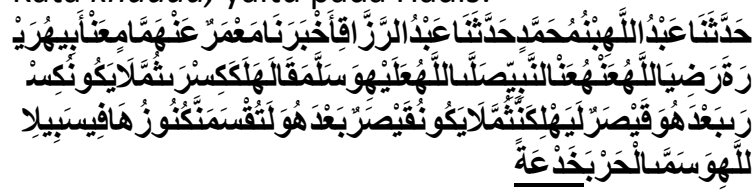

"Telah bercerita kepada kami ['Abdullah bin Muhammad] telah bercerita kepada kami ['Abdur Rozzaq] telah mengabarkan kepada kami [Ma'mar] dari [Hammam] dari [Abu Hurairah radliallahu 'anhu] dari Nabi Shallallahu'alaihiwasallam bersabda: " Kisro (Raja Persia) akan hancur dan tidak akan ada lagi Kisro setelah itu. Sedangkan Qoishor (Raja Romawi) pasti akan hancur dan tidak ada lagi Qoishor setelah itu. Dan sungguh kalian akan mambagi-bagikan perbendaharaan kekayaan mereka di jalan Allah". Dan Beliau mengistilahkan perang adalah tipu daya. (HR. Buhkari No. 2803).

Asad dan al-Maududi(1988)menafsirkan tiga (3) kalimat padanan strategi di atas dengan terma-terma sebagai berikut, yaitu: Scheme (skema-rencana-pola-bagan-susunan-ikhtisarringkasan); plot (merencanakan-alur-isi cerita); device (alat-perlengkapan-rencana-akalmuslihat); contrived (merancangmerencanakan-menciptakan-me(reka)menyusun-memikirkan-memikir-berusahamencari akal); try to outwit (latihan-mencoba untuk mengecoh); guile (akal kancilkecerdasan-tipu-muslihat); artful scheme (seni 
merancang); artifice (kecerdasan-kelicikankeahlian); sought to do (berusaha untuk); artful (licik-licin); trap (perangkap-penjerat); deceive (mengakali-memperdayakan); strategy (siasatmuslihat); stratagem (tipuan).

Muhammad Quraish Shihab (2007, hlm. 403) pakar Tafsir al-Quran menjelaskan bahwa makar (tipu daya) dalam bahasa al-Quran adalah, "mengalihkan pihak lain dari apa yang dikehendaki dengan cara tersembunyi (tipudaya)." Ada dua macam tipu-daya, yaitu yang baik dan yang buruk. Tipu-daya yang baik adalah tipu-daya yang mengakibatkan kebaikan, sebaliknya makar yang buruk adalah makar yang mengakibatkan keburukan.

Mestinya, dari pelacakan ketiga terma itulah konsepsi strategi pendekatan pembelajaran bisa dibangun dan dibahas. Namun demikian, karena keterbatasan kesempatan penulis, dalam Kajian ini hanya sekedar menyesuaikan dengan konsepsi yang lumrah dalam dunia pendidikan. Schumaker dan Deshler (2006, hlm. 121-156) mendefinisikan strategi pembelajaran, learning strategy, dengan, "an individuals approach to a task. It includes how a person thinks and acts when planning, executing, and evaluating performance on a task and its outcomes."

B.F., Jones, A.S. Palincsar, D.S. , Ogle, dan E.G. Carr (1987), mendefinisikan Strategic learning dengan kalimat:"is an approach to evaluation that we are helping to grow. Strategic learning means using evaluation to help organizations or groups learn quickly from their work so they can learn from and adapt their strategies. It means integrating evaluation and evaluative thinking into strategic decision making and bringing timely data to the table for reflection and use. It means making evaluation a part of the intervention-embedding it so that it influences the process. We think strategic learning has tremendous potential, particularly for complex and dynamic change strategies. Our work is further defining this concept, increasing the fields awareness about this approach, and developing resources and tools that evaluators can use to apply it."

MenurutMohUsmanUzer(2013, hlm. 5) Pendidikan merupakan suatu proses pendewasaan peserta didik melalui pembelajaran secara sadar dan terencana untuk secara aktif mengoptimalkan potensi yang ada pada diri peserta didik, sehingga terbentuk watak, karakter, dan kepribadian sebagai manusia seutuhnya. Tujuan dalam pendidikan akan tercapai apabila terjalin suatu interaksi yang baik antarguru dan siswa. Untuk menciptakan hal itu, tentu dibutuhkan strategi yang jitu, sehingga proses pembelajaran dapat berjalan dengan baik.

Abdul Majid (2013, hlm. 3) mengemukakanlstilah strategi (strategy) berasal dari "kata benda" dan "kata kerja" dalam bahasa Yunani. Sebagai kata benda, strategos merupakan gabungan kata stratos (militer) dengan "ago" (memimpin). Sebagai kata kerja, stratego berarti merencanakan (to plan). Jadi strategi adalah suatu pola yang direncanakan dan ditetapkan secara sengaja untuk melakukan kegiatan atau tindakan. Strategi mencakup tujuan kegiatan, siapa yang terlibat dalam kegiatan, isi kegiatan, proses kegiatan, dan sarana penunjang kegiatan. Istilah pembelajaran (intruction) bermakna sebagai upaya untuk membelajarkan seseorang atau kelompok orang melalui berbagai upaya (effort) dan berbagai strategi, metode dan pendekatan ke arah pencapaian tujuan yang telah direncanakan.

WinaSanjaya (2007, hlm. 126) setidaknya, ada dua hal yang patut dicermati dari pengertian tersebut, Pertama, strategi pembelajaran merupakan rencana tindakan (rangkaian kegiatan) termasuk penggunaan metode dan pemanfaatan berbagai sumber daya atau kekuatan dalam pembelajaran. Inti penguyusunan strategi baru sampai pada proses penyusunan rencana kerja belum sampai pada tindakan. Kedua, strategi disusun untuk mencapai tujuan tertentu. Artinya, arah dari semua keputusan penyusunan strategi adalah pencapaian tujuan.

Dengan demikian tujuan pembelajaran dapat tercapai dengan baik, jika pendidik dapat menerapkan strategi pendekatan pembelajaran yang menarik dan tidak didominasi hanya dengan satu pendekatan saja, seperti pendekatan ceramah. Umumnya pendekatan dalam pembelajaran yang dilakukan banyak menggunakan pendekatan 
ceramah.Padahal, pendeketan seperti ini sangat tidak efektif dalam pembelajaran.

Muhammad Arifin (1994, hlm. 104) mengemukakan pendekatan tersebut hanya menjadikan peserta didik sebagai obyek belajar. Sejatinya, pembelajaran yang baik adalah ketika peserta dapat dijadikan subyek belajar. Menjadikan peserta didik sebagai obyek belajar dapat memangkas kreatifitas dalam pembelajaran dan menjadikan mereka tidak berkembang. Di sisi lain, pembelajaran yang dilakukan di kelas cenderung menjadi membosankan. Untuk menghindari kondisi tersebut, strategi pendekatan dalam pembelajaran mutlak dibutuhkan keberadaannya.

\section{Pengertian Pendekatan Pembelajaran}

Pendekatan adalah suatu proses untuk mengidentifikasikan kebutuhan-kebutuhan, menseleksi problema-problema, menemukan persyaratan-persyaratan untuk memecahkan problema-problema, memilih alternatifalternatif pemecahan, mendapatkan metodemetode dan alat-alat serta mempersamakannya, hasil-hasilnya dievaluasi, serta melakukan revisi yang diperlukan terhadap sebagian atau seluruh sistem yang telah diciptakan. Pendekatan dapat pula dimaknai sebagai proses, perbuatan, atau cara untuk mendekati sesuatu.

MenurutOemar Hamalik(2007,hlm. 57)pembelajaran adalah suatu kombinasi yang tersusun meliputi unsur-unsur manusiawi, material, fasilitas, perlengkapan, dan prosedur yang saling mempengaruhi untuk mencapai tujuan pembelajaran. Manusia yang terlibat dalam sistem pembelajaran terdiri dari siswa, guru, dan tenaga lainnya, misalnya tenaga laboratorium, tenaga perpustakaan dan sebagainya. Material meliputi buku-buku, papan tulis, spidol, fotografi, slide, film, audio visual dan semacamnya. Fasilitas dan perlengkapan, terdiri dari ruangan kelas, perlengkapan audio visual, juga komputer. Prosedur, meliputi jadwal dan metode penyampaian informasi, praktik, belajar, ujian dan sebagainya. Di sisi lain, pembelajaran dapat dikatakan sebagai usaha sadar dan disengaja oleh guru untuk membuat siswa belajar.
Dari kedua pengertian tersebut pendekatan pembelajaran bisa diartikan sebagai cara kerja yang mempunyai sistem untuk memudahkan pelaksanaan proses pembelajaran dan membelajarkan siswa guna membantu untuk mengotimalkan potensi yang dimilikinya. Sehingga, tujuan pembelajaran dapat dicapai. Salah satu tujuan pembelajaran adalah menjadikan siswa aktif dalam mengikuti setiap pelajaran di kelas. Dengan begitu kondisi kelas akan menjadi lebih hidup, karena pendidik telah berhasil memposisikan siswa sebagai subyek belajar (http://klubguru.com).

\section{Trianto}

(2007,

$\mathrm{hlm}$.

1)berpendapatbahwa pendekatan adalah konsep dasar yang mewadahi, menginsipirasi, menguatkan, dan melatari metode pembelajaran dengan cakupan teoretis tertentu. Metode pembelajaran adalah prosedur, urutan, langkah-langkah, dan cara yang digunakan guru dalam pencapaian tujuan pembelajaran. Dapat dikatakan bahwa metode pembelajaran merupakan jabaran dari pendekatan. Satu pendekatan dapat dijabarkan ke dalam berbagai metode pembelajaran. Dapat pula dikatakan bahwa metode adalah prosedur pembelajaran yang difokuskan ke pencapaian tujuan. Dari metode, teknik pembelajaran diturunkan secara aplikatif, nyata, dan praktis di kelas saat pembelajaran berlangsung. Teknik adalah cara kongkret yang dipakai saat proses pembelajaran berlangsung. Guru dapat berganti-ganti teknik meskipun dalam koridor metode yang sama. Satu metode dapat diaplikasikan melalui berbagai teknik pembelajaran.

KokomKomalasari, (2010, hlm 2) mengemukakanbahwa pembelajaran dapat dilihat dari dua sudut pandang, pertama, pembelajaran dipandang sebagai suatu sistem, terdiri dari sejumlah komponen yang terorganisasi antara lain tujuan pembelajaran, materi pembelajaran, strategi dan metode pembelajaran, media pembelajaran atau alat peraga, pengorganisasian kelas, evaluasi pembelajaran, dan tindak lanjut pembelajaran (remidial dan pengayaan). Kedua, pembelajaran dipandang sebagai suatu proses, maka pembelajaran merupakan rangkaian upaya atau kegiatan guru dalam rangka membuat siswa belajar, proses tersebut meliputi; (i) persiapan, dimulai dari 
merencanakan program pengejaran tahunan, semester, dan penyusunan persiapan mengajar (lesson plat); (ii) Melaksanakan kegiatan pembelajaran dengan mengacu pada persiapan pembelajaran yang telah disiapkannya; (iii) Menindaklanjuti pembelajaran yang telah dikelolannya.

\section{Macam-macam Pendekatan Pembelajaran}

Salah satu faktor penunjang dalam pembelajaran adalah penggunaan pendekatan pembelajaran. Semakin banyak pendekatan yang digunakan akan semakin tidak membosankan pembelajaran yang dilakukan. Di sisi lain, dapat membangkitkan potensi pendidik untuk menjadi guru yang kreatif. Adapun beberapa pembelajaran yang dapat digunakan di kelas adalah sebagai berikut:a)Pendekatan ekspository learning.Pendekatan ini dilatarbelakangi anggapan terhadap siswa bahwa mereka masih kosong dengan ilmu. Pendekatan ini sangat cocok diterapkan pada materi ketauhidan. Dalam pendekatan ini guru berfungsi sebagai disainer dan sebagai aktor. Dalam sistem ini, Zaenal Mustakim (2012, h. 72), guru menyajikan materi ajar dalam bentuk yang telah dipersiapkan secara rapi, sistematis, dan lengkap. Sehingga anak didik tinggal menyimak dan mencernanya saja secara tertib dan teratur. Langkah-langkah pendekatan ekspository learning adalah: 1) Penentuan tema pokok bahasan. Penentuan tema pokok bahasan perlu dilakukan pendidik sebelum melakukan pembelajaran, sehingga pendidik telah memiliki tema yang akan disampaikan ketika hendak memberikan pembelajaran dengan pendekatan ekspository learning. Sehingga ketika berhadapan dengan pesert didik, pendidik telah siap dengan tema yang akan disajikan. 2) Menyusun pokok bahasan. Setelah menentukan tema langkah selanjutnya yang ditempuh pendidik dalam menggunakan pendekatan ekspository learning adalah menyusun pokok bahasan. Penyusunan pokon bahasan ini diperlukan agar pembelajaran yang disampaikan pendidik menjadi lebih sistematis. Sehingga lebih mudah dipahami oleh peserta didik. 3) Menjelaskan materi secara baik. Guru yang handal bukan sekadar guru yang mampu membuat tema dan pokok bahasan, tetapi mampu mula menyajikan dan menjelaskan materi dalam pembelajaran secara baik. Dalam konteks ini, guru diharuskan menguasai setiap tema yang hendak diberikan, sebelum disampaikan kepada setiap murid. Penjelasan yang baik dari materi yang diberikan dapat melahirkan pemahaman kepada setiap murid terhadap materi yang telah disampaikan. 4) Melakukan kegiatan revisi.Kegiatan revisi dalam metode pembelajaran eksplository learning mutlak dibutuhkan. Kegiatan ini dilakukan untuk memberi masukan kepada setiap murid atas setiap kegiatan belajar yang telah dilakukan. Dengan begitu, murid menjadi tahu hal salah dan benar dalam pembelajaran. Di sisi lain, melalui kegiatan tersebut menurut Pupuh dan Sobry (2009, hlm. 30-31) bahwapendidik dapat mengukur keberhasilan dalam memberikan pelajaran kepada setiap murid.b) Pendekatan Enquiry Learning.Enquiry Learning adalah belajar mencari dan menemukan sendiri. Dalam pendekatan pembelajaran ini guru menyajikan bahan pelajaran tidak dalam bentuk yang final, tetapi anak didik diberi peluang untuk mencari dan menemukanya sendiri dengan mempergunakan teknik pendekatan pemecahan masalah. Pendekatan Enquiry Learning dilatarbelakangi oleh anggapan seorang pendidik bahwa siswa merupakan subjek dan objek belajar yang telah memiliki ilmu pengetahuan. Pendekatan ini dapat membangkitkan kreatifitas setiap siswa dalam mengikuti kegiatan pembelajaran.

c)Pendekatan Mastery Learning.Mastery Learning atau belajar tuntas diangkat dari pengertian tentang apa yang disebut dengan "situasi belajar". Dalam situasi belajar terdapat aneka macam kecepatan individu sebagai peserta belajar. Ada murid yang cepat menguasai pelajaran sehingga ia dapat berpartisipasi penuh dalam proses interaksi kelas. Di samping itu ada pula murid-murid yang lambat sehingga tingkat partisipasinya rendah. Mereka yang terakhir ini akan mengalami kesukaran dalam mengikuti kecepatan belajar yang digunakan guru. Mereka akan mengalami kesulitan apalagi bantuan yang diberikan terhadap mereka kurang sekali. Belajar tuntas didasarkan pada kondisi objektif bahwa setiap siswa dapat 
mencapai belajar tuntas, namun biasanya membutuhkan waktu yang berbedabeda.d)Pendekatan Kompetensi. Kompetensi menunjukan kepada kemampuan melaksanakan sesuatu yang diperoleh melalui pembelajaran dan latihan. Dalam hubungannya dengan proses pembelajaran, kompetensi menunjuk kepada perbuatan (performance) yang bersifat rasional dan memenuhi spesifikasi tertentu dalam proses belajar. Dikatakan perbuatan karena perilaku yang dapat diamati meskipun sebenarnya sering kali terlihat pula proses yang tidak nampak seperti pengambilan keputusan atau pilihan sebelum perbuatan dilakukan.e)Pendekatan Lingkungan. Pendekatan lingkungan merupakan suatu pendekatan pembelajaran yang berusaha untuk meningkatkan keterlibatan peserta didik melalui pendayagunaan lingkungan sebagai sumber belajar. Pendekatan ini berasumsi bahwa kegiatan pembelajaran akan menarik perhatian peserta didik jika yang dipelajari diangkat dari lingkungan, sehingga apa yang dipelajari berhubungan dengan kehidupan dan berfaedah bagi lingkungannya.Pembelajaran berdasarkan pendekatan lingkungan dapat dilakukan dengan dua cara: 1) Membawa peserta didik ke lingkungan untuk kepentingan pembelajaran. Hal ini bisa dilakukan dengan metode karya wisata, metode pemberian tugas, dan lain-lain. 2) Membawa sumbersumber dari lingkungan ke sekolah (kelas) untuk kepentingan pembelajaran. Sumber tersebut bisa sumber asli, seperti nara sumber, bisa juga sumber tiruan, seperti model dan gambar.f)Pendekatan Kontekstual. Kata "kontekstual" berasal dari "konteks" yang dalam Kamus Besar Bahasa Indonesia mengandung dua arti: 1) bagian sesuatu uraian atau kalimat yang dapat mendukung atau menambah kejelasan makna; 2) situasi yang ada hubungan dengan suatu kejadian. Pembelajaran kontekstual adalah suatu proses pendidikan yang bertujuan membantu siswa melihat makna dalam bahan pelajaran yang mereka pelajari dengan cara menghubungkannya dengan konteks kehidupan mereka sehari-hari, yaitu dengan konteks lingkungan pribadi, sosial, dan budaya (Kunandar 2007, hlm. 295).
Menurut Syaiful Bahri (2014, 46) Pendekatan kontekstual (contekstual teaching and learning) yang sering disebut CTL. CTL merupakan konsep pembelajaran yang menekankan kepada keterkaitan materi pembelajaran dengan dunia kehidupan peserta didik secara nyata, sehingga para peserta didik mampu menghubungkan dan menerapkan kompetensi hasil belajar dalam kehidupan sehari-hari. Pembelajaran konstektual melibatkan tujuh komponen utama pembelajaran, yaitu: 1) Kontruktivisme (contrucism) yang dimaksud kontruktivisme adalah pengetahuan dibangun sedikit demi sedikit, yang hasilnya diperluas melalui konteks yang terbatas (sempit) dan tidak secara mendadak. 2) Menemukan (inqury) menemukan merupakan kegiatan inti dari proses pembelajaran kontekstual. Pengetahuan dan ketrampilan yang diperoleh siswa diharapkan bukan hasil mengingat seperangkat fakta-fakta, tetapi hasil dari menemukan sendiri. 3) Bertanya (questioning) dalam proses pembelajaran bertanya dipandang sebagai kegiatan guru untuk mendorong, membimbing, dan menilai kemampuan berpikir siswa. Bagi siswa kegiatan bertanya merupakan bagian penting dalam melaksanakan pembelajaran yang berbasis penemuan, yaitu menggali informasi, mengkorfirmasikan apa yang sudah diteliti dan mengarahkan perhatian pada aspek yang belum diketahui. 4) Masyarakat belajar (learning community) konsep masyarakat belajar ini menyarankan agar hasil pembelajaran diperoleh dari hasil kerjasama dengan orang lain. Hasil pembelajaran diperoleh dari berbagai antar teman, antar kelompok dan antar yang tahu dengan yang tidak tahu. Masyarakat belajar akan memberi informasi yang diperlukan oleh teman bicaranya dan sekaligus juga meminta informasi yang diperlukan dari teman belajarnya. 5) Pemodelan (Modeling) maksudnya adalah bahwa sebuah pembelajaran ketrampilan atau pengetahuan tertentu harus ada model yang ditiru. Pemodelan akan lebih mengefektifkan pelaksanaan pembelajaran dengan pendekatan kontekstual untuk dirimu, diadaptasi atau dimodifikasi. 6) Refleksi (Reflekstion) refleksi adalah berpikir kembali tentang materi yang 
baru dipelajari, merenungkan bagi aktifitas yang telah dilakukan atau mengevaluasi kembali bagaimana belajar yang telah dilakukan. Refleksi berguna untuk mengevaluasikan diri, koreksi, perbaikan atau peningkatan diri. 7) Penilaian yang sebenarnya (authentic assesmen) adalah penilaian yang dilakukan secara komprehensif berkenaan dengan seluruh aktifitas pembelajaran yang meliputi proses dan produk belajar sehingga seluruh usaha siswa yang telah dilakukan mendapat penghargaan.

Pendekatan-pendekatan tersebut jika digunakan dalam pembelajaran dapat menjadikan pendidik tidak terfokus mengajar hanya pada satu pendekatan saja. Pendekatan yang variatif sangat dibutuhkan keberadaannya dalam proses pembelajaran. Melalui berbagai pendekatan pembelajaran pendidik dan peserta didik membangun suasana belajar yang menyenangkan.

\section{Ayat-ayat Terkait Pendekatan Pembelajaran}

Sebagai pedoman hidup umat Islam, alQuran memberikan perhatian pula dalam pembelajaran. Setidaknya terdapat beberapa surat dalam al-Quran yang dapat dijadikan pijakan untuk melakukan strategipendekatan pembelajaran dalam Islam, seperti;

1)QS. an-Nahl [16]: 125:

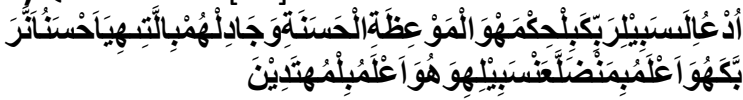

"(Wahai Nabi Muhmmad SAW) Serulah (semua manusia) kepada jalan (yang ditunjukkan) Tuhan Pemelihara kamu dengan hikmah (dengan kata-kata bijak sesuai dengan tingkat kepandaian mereka) dan pengajaran yang baik dan bantalah mereka dengan (cara) yang terbaik. Sesungguhnya Tuhan pemelihara kamu, Dialah yang lebih mengetahui (tentang siapa yang tersesat dari jalan-Nya dan dialah yang lebih mengetahui orang-orang yang mendapat petunjuk)."

Dari surah an-Nahl ini tercantum tiga pendekatan pembelajaran, diantaranya, pertama, pendekatan hikmah. Kata hikmah dalam tafsir al-Misbah berarti "yang paling utama dari segala sesuatu, baik pengetahuan maupun berbuatan". Dalam bahasa Arab hikmah bermakna kebijaksanaan dan uraian yang benar. Dengan kata lain hikmah adalah mengajak kepada jalan Allah dengan cara keadilan dan kebijaksanaan, selalu mempertimbangkan berbagai faktor dalam proses belajar mengajar, baik faktor subjek, obyek, sarana, media dan lingkungan pengajaran (Abi Bakar Jabir;2003, h. 169).Pertimbangan pemilihan metode dengan memperhatikan peserta didik diperlukan kearifan agar tujuan pembelajaran tercapai dengan maksimal. Selain itu dalam penyampaian materi maupun bimbingan terhadap peserta didik hendaknya dilakukan dengan cara yang baik yaitu dengan lemah lembut, tutur kata yang baik, serta dengan cara yang bijak.

Proses belajar mengajar dapat berjalan dengan baik dan lancar manakala ada interaksi yang kondusif antara guru dan peserta didik. Komunikasi yang arif dan bijaksana memberikan kesan mendalam kepada para siswa sehingga "teacher oriented" akan berubah menjadi "student oriented". Guru yang bijaksana akan selalu memberikan peluang dan kesempatan kapada siswanya untuk berkembang menjadi lebih. Dengan pendekatan hikmah dalam pembelajaran, seorang pendidik semakin mengerti kebutuhan peserta didik.

Kedua, pendekatan nasihat atau pengajaran yang baik. Dalam al-Quran nasihat yang baik dibahasakan dengan mauidzah hasanah. Kata ini terdiri dari dua kata Mauizhah dan Hasanah. Mauizhah terambil dari kata waazha yang bermakna nasihat. Sementara itu hasanah bermakna baik. Jika disatukan maka memiliki makna nasihat yang baik (Miftahul Huda; 2008, h. 315). Dalam hal ini, Allah SWT berfirman:

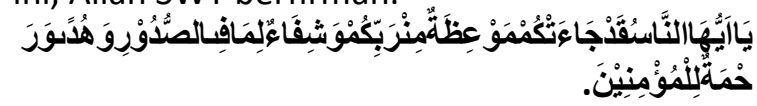

"Hai segenap manusia, telah datang kepada kalian mauizhah dari pendidikanmu, penyembuh bagi penyakit yang bersemayam di dalam dada, petunjuk dan rahmat bagi orangorang yang beriman." (QS. Yunus [10]: 57)

Pendekatan dengan menggunakan nasihat yang baik merupakan pendekatan yang diperlukan dalam setiap proses pembelajaran. Pendekatan seperti ini berguna untuk membangun kedekatan antarguru dan murid. Di sisi lain, membangung kesadaran bagi setiap 
guru, jika mereka memiliki tugas sebagai pengganti orangtua murid di rumah. Kesadaran ini dapat dijadikan alat bagi guru untuk tidak sungkan dalam menasehati setiap muridmuridnya untuk melakukan setiap kebaikan.

Ketiga, Pendekatan Diskusi. Dalam bahasa Arab diskusi bermakna jidal. Pendekatan diskusi yang dimaksud dalam alQuran ini adalah diskusi yang dilaksanakan dengan tata cara yang baik dan sopan. Yang mana tujuan dari metode ini ialah untuk lebih memantapkan pengertian dan sikap pengetahuan mereka terhadap suatu masalah.

Definisi diskusi sendiri adalah cara penyampaian bahan pelajaran dengan memberikan kesempatan kepada siswa untuk membicarakan, menganalisa guna mengumpulkan pendapat, membuat kesimpulan atau menyusun berbagai alternatif pemecahan masalah. Dalam kajian metode mengajar disebut metode "hiwar" (dialog). Diskusi memberikan peluang sebesar-besarnya kepada para siswa untuk mengeksplor pengetahuan yang dimilikinya kemudian dipadukan dengan pendapat siswa lain. Satu sisi mendewasakan pemikiran, menghormati pendapat orang lain, sadar bahwa ada pendapat di luar pendapatnya. Di sisi lain siswa merasa dihargai sebagai individu yang memiliki potensi, kemampuan dan bakat bawaannya.

2)QS.al-Ahzab [33]:21

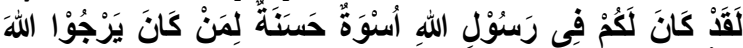

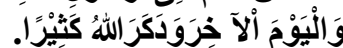

"Sesungguhnya telah ada pada pribadi Rasulullah itu suri tauladan yang baik bagimu (yaitu) bagi orang yang mengharap (rahmat) Allah dan hari akhir dan dia banyak berdzikir kepada Allah."

Dari ayat di atas setidaknya terdapat pendekatan yang dapat dilakukan dalam pembelajaran, yaitu pendekatan keteladanan. Pendekatan keteladanan diperlukan untuk membentuk karakter peserta didik. Pendekatan ini dilakukan oleh setiap guru dengan mencontohkan perbuatan-perbuatan baik kepada peserta didik, misalnya dengan selalu mengucapkan salam ketika hendak masuk kelas, membuang sampah di tempatnya dan sebagainya (Armai Arief;2002, h. 109).

Kegiatan-kegiatan tersebut jika dilakukan secara terus-menerus oleh guru tentu akan ditiru oleh peserta didik. Manusia banyak belajar dengan cara meniru. Dari kecil ia sudah meniru kebiasaan atau tingkah laku kedua orangtua dan saudara-saudaranya. Misalnya, ia mulai belajar bahasa dengan berusaha meniru kata-kata yang diucapkan saudaranya berulang-ulang kali.

Begitu juga dalam hal berjalan ia berusaha meniru cara menegakkan tubuh dan menggerakkan kedua kaki yang dilakukan orang tua dan saudara-saudaranya. Demikianlah manusia belajar banyak kebiasaan dan tingkah laku lewat peniruan kebiasaan maupun tingkah laku keluarganya. Al-Quran sendiri telah mengemukakan contoh bagaimana manusia belajar melalui meniru. Ini dikemukakan dalam kisah pembunuhan yang dilakukan Qabil terhadap saudaranya Habil. Bagaimana ia tidak tahu cara memperlakukan mayat saudaranya itu. Maka Allah memerintahkan seekor burung gagak untuk menggali tanah guna menguburkan bangkai seekor gagak lain. Kemudian Qabil meniru perilaku burung gagak itu untuk mengubur mayat saudaranya Habil. Allah berfirman dalam QS. Al-Maidah ayat 31:

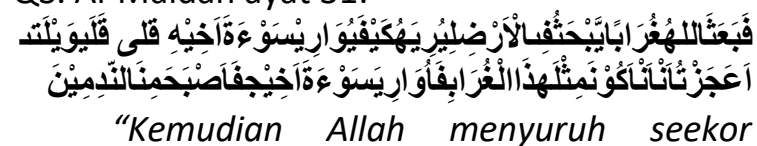

burung gagak menggali-gali di bumi untuk memperlihatkan kepadanya (Qabil) bagaimana seharusnya menguburkan mayat saudaranya. Berkata Qabil: "Aduhai celaka aku, mengapa aku tidak mampu berbuat seperti burung gagak ini. Lalu aku dapat menguburkan mayat saudaraku ini?". Karena itu jadilah dia seorang diantara orang-orang yang menyesal."

MenurutAbuddinNata(2001, h. 95) melihat tabiat manusia yang cenderung untuk meniru dan belajar banyak dari tingkah lakunya lewat peniruan. Maka, teladan yang baik sangat penting artinya dalam pendidikan dan pengajaran. Nabi Muhammad SAW. sendiri menjadi suri tauladan bagi para sahabatnya, dari beliau mereka belajar bagaimana mereka melaksanakan berbagai ibadah. Ada sebuah Hadist yang menceritakan bahwa para sahabat meniru shalat sunnah witir Nabi SAW:

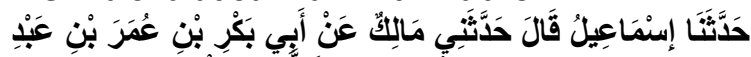

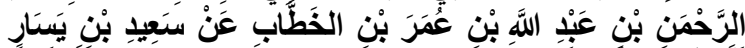

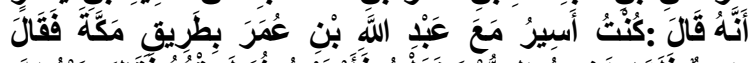

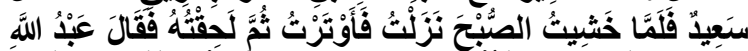

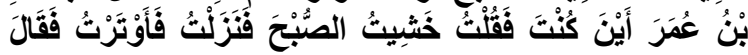




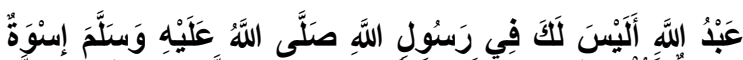

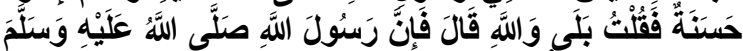

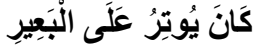

"Telah menceritakan kepada kami Ismail berkata, telah menceritakan kepadaku Malik dari Abu Bakar bin Umar bin Abdurrahman bin Abdullah bin Umar bin Al Khaththab dari Sad bin Yasar bahwa dia berkata: "Aku bersama Abdullah bin Umar pernah berjalan di jalanan kota Makkah. Said berkata, "Ketika aku khawatir akan (masuknya waktu) Shubuh, maka aku pun singgah dan melaksanakan shalat witir. Kemudian aku menyusulnya, maka Abdullah bin Umar pun bertanya, "Dari mana saja kamu?" Aku menjawab, "Tadi aku khawatir akan (masuknya waktu) Shubuh, maka aku singgah dan melaksanakan shalat witir." Abdullah bin Umar berkata, "Bukankah kamu telah memiliki suri tauladan yang baik pada diri Rasulullah shallallahu alaihi wasallam?" Aku menjawab, "Ya. Demi Allah." Abdullah bin Umar berkata, "Sesungguhnya Rasulullah shallallahu alaihi wasallam pernah shalat witir di atas untanya." (H.R. Bukhari)

Asnellyllyas(1998,

$\mathrm{h}$.

berpendapatbahwa melalui suri tauladan yang baik yang sering dipraktekkan guru, peserta dapat belajar kebiasaan baik dan akhlak yang mulia. Tanpanya, kedua hal tersebut sulit untuk diwujudkan. Yang perlu digarisbawahi adalah tugas setiap guru di sekolah tidak sekedar mengajar dan memberikan pengetahuan. Tetapi perlu menjadi teladan bagi setiap muridmuridnya, sehingga mereka menjadi manusiamanusia yang berkarakter.

3. QS. Yusuf [12]: 2-3

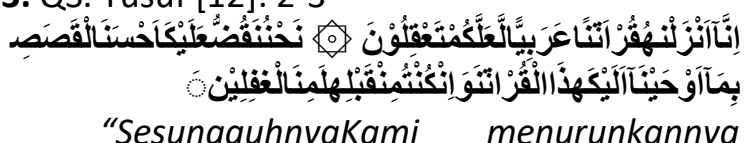

"SesungguhnyaKami menurunkannya berupa Al Quran dengan berbahasa Arab, agar kamu memahaminya. Kami menceritakan kepadamu kisah yang paling baik dengan mewahyukan Al Quran ini kepadamu, dan Sesungguhnya kamu sebelum (kami mewahyukan) nya adalah Termasuk orangorang yang belum mengetahui".

Ayat di atas menerangkan, bahwa Tuhan menurunkan Al-Quran dengan memakai bahasa Arab kepada Nabi Muhammad saw. Dan Nabi menyampaikan kepada para sahabat dengan jalan ceramah, maka pendekatan pembelajaran yang diajarkan al-Quran dalam ayat ini adalah pendekatan ceramah atau pendekatan lisan. Pendekatan ceramah masih merupakan pendekatan mengajar yang masih dominan dipakai, khususnya di sekolah-sekolah tradisional (Ahmad Tafsir; 2003 h. 33).

Pendekatan ini merupakan pendekatan yang sering digunakan dalam menyampaikan atau mengajak orang mengikuti ajaran yang telah ditentukan. pendekatan ceramah sering disandingkan dengan kata khutbah. Dalam alQuran sendiri kata tersebut diulang sembilan kali. Bahkan ada yang berpendapat pendekatan ceramah ini dekat dengan kata tabligh, yaitu menyampaikan sesuatu ajaran. Pada hakikatnya kedua arti tersebut memiliki makna yang sama yakni menyampaikan suatu ajaran.

Dengan demikian pendekatan ceramah merupakan pendekatan paling klasik yang sampai saat masih tetap berguna digunakan dalam proses pembelajaran. Namun akan lebih menarik jika pendekatan tersebut dilakukan dengan disandingkan pendekatan-pendekatan yang lain. Sehingga pembelajaran tidak terpaku hanya terfokus kepada guru.

4. QS. al-Ankabut [29]: 20:

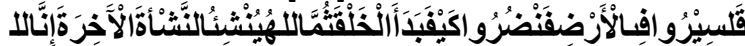

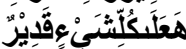

Katakanlah: "Berjalanlah di (muka) bumi. Maka perhatikanlah bagaimana Allah menciptakan (manusia) dari permulaannya. Kemudian Allah menjadikannya sekali lagi. Sesungguhnya Allah Maha Kuasa atas segala sesuatu

Menurut Mardeli (2011, h. 11) perhatian al-Quran dalam menyeru manusia untuk mengamati dan memikirkan alam semesta dan makhluk-makhluk yang ada di dalamnya, mengisyaratkan dengan jelas perhatian alQuran dalam menyeru manusia untuk belajar, baik melalui pengamatan terhadap berbagai hal, pengalaman praktis dalam kehidupan sehari-hari, ataupun lewat interaksi dengan alam semesta. Ini semua bisa dilakukan dengan pendekatan pengalaman praktis (trial and error).

Dengan demikian pendekatan pembelajaran yang terdapat dalam ayat ini adalah pendekatan pengalaman praktis (trial and error). Pendekatan ini dapat dilakukan melalui percobaan dan pengamatan. Sehingga 
menghasilkan pengalaman dalam percobaan dan pengamatan tersebut. Namun terkadang tidak semua percobaan dan pengamatan itu menghasilkan hal-hal yang benar, bahkan terkadang salah. Di sinilah manusia dapat terus melakukan percobaan, hingga mendapat kebenaran. Dengan demikian, manusia belajar lewat trial and error, (belajar dari mencoba dan membuat salah) memberikan respons terhadap kesalahan-kesalahan hingga dapat mencari jalan baru atau jalan keluar dari percobaan dan pengamatan yang dilakukannya.

Nabi SAW sendiri telah mengemukakan tentang pentingnya belajar dari pengalaman praktis dalam kehidupan yang dinyatakan dalam Hadist yang di tahrij oleh Imam Muslim berikut:

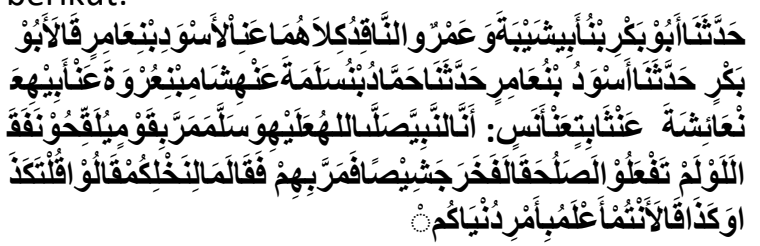

"Abu Bakar bin Abi Saybah dan Amr alNaqidh bercerita kepadaku. Keduanya dari alAswad bin Amir. Abu Bakr berkata, Aswad bin Amir bercerita kepadaku, Hammad bin Salmah bercerita kepadaku, dari Hisham bin Urwah dari ayahnya dari Aisyah dandari Tsabit dari Anas Radhiyallahuanhu:Bah wa Nabi shallallahu alaihi wasallam pernah melewati suatu kaum yang sedang mengawinkan pohon kurma lalu beliau bersabda:Sekiranya mereka tidak melakukannya, kurma itu akan (tetap) baik. Tapi setelah itu, ternyata kurma tersebut tumbuh dalam keadaan rusak. Hingga suatu saat Nabi shallallahu alaihi wasallam melewati mereka lagi dan melihat hal itu beliau bertanya: Adaapa dengan pohon kurma kalian? Mereka menjawab; Bukankah anda telah mengatakan hal ini dan hal itu? Beliau lalu bersabda: Kalian lebih mengetahui urusan dunia kalian.

Hadis di atas mengisyaratkan tentang belajarnya manusia membuat respon-respon baru lewat pengalaman praktis dari berbagai situasi baru yang dihadapinya, dan berbagai jalan pemecahan dari masalah-masalah yang dihadapinya. Mengenai jenis belajar lewat pengalaman praktis al-Quran memberikan jawaban dengan; "Sesungguhnya, dalam penciptaan langit dan bumi, dan pergantian malam dan siang, terdapat tanda-tanda (kebesaran Allah) bagi orang yang berakal, (yaitu) orang-orang yang mengingat Allah sambil berdiri, duduk, atau dalam keadaan berbaring, dan mereka memikirkan tentang penciptaan langit dan bumi (seraya berkata), "Ya Tuhan kami, tidaklah Engkau menciptakan semua ini sia-sia; Mahasuci Engkau, lindungilah kami dari azab neraka."(Jami Al Bayan anTawilAyi Al Quran: TafsirAthThabari, terj, AkhmadAffandi; 2008, hlm. 303308).

Dengan demikian pendekatan melalui pengamatan dapat membawa manusia kepada pengalaman-pengalaman baru, meskipun terkadang pengalaman tersebut banyak menghasilkan kesalahan. Namun dari situlah manusia dapat belajar dan menemukan sesuatu yang baru dan berguna bagi kemanusiaan. Tanpa ada keberanian untuk melakukan percobaan-percobaan dengan trial and error, pengetahuan baru sulit untuk di dapat. Semakin banyak melakukan percobaan dan kesalahan, semakin banyak ilmu dan pengetahuan yang di dapat.

\section{Simpulan}

Salah satu faktor penunjang dalam pembelajaran adalah penggunaan pendekatan pembelajaran. Semakin banyak pendekatan yang digunakan akan semakin tidak membosankan pembelajaran yang dilakukan. Di sisi lain, dapat membangkitkanpotensipendidikuntuk menjadi guru yang kreatif.

Sebagai pedoman hidup umat Islam, alQuran memberikan perhatian pula dalam pembelajaran. Setidaknya terdapat beberapa surat dalam al-Quran yang dapat dijadikan pijakan untuk melakukan strategi pendekatan pembelajaran dalam Islam, yaitu: a) pendekatan hikmah, selalu memberikan peluang dan kesempatan kapada siswanya untuk berkembang menjadi lebih. Dengan pendekatan hikmah dalam pembelajaran, seorang pendidik semakin mengerti kebutuhan peserta didik, b) pendekatan nasihat atau pengajaran yang baik, c) Pendekatan diskusi,dalam bahasa Arab diskusi bermakna jidal. Pendekatan diskusi yang dimaksud dalam 
al-Quran ini adalah diskusi yang dilaksanakan dengan tata cara yang baik dan sopan, d) Pendekatan keteladanan diperlukan untuk membentuk karakter peserta didik, e) pendekatan ceramah atau pendekatan lisan. Pendekatan ceramah masih merupakan pendekatan mengajar yang masih dominan dipakai, khususnya di sekolah-sekolah tradisional, dan f) pendekatan pengalaman praktis (trial and error), yaitudilakukan melalui percobaan dan pengamatan.

\section{DaftarPustaka}

[1] Abdul Majid. (2013). Strategi Pembelajaran. Bandung: PT Remaja Rosdakarya.

[2] Abdullah bin Muhammad bin Abdurrahman Alu Syaikh, Lubaabut Tafsir min Ibni Katsiir: Ringkasan Ibnu Katsir. terj. M. Abdul Ghoffar. Jakarta: Pustaka Imam Asy-Syafii.

[3] Abi Bakar Jabir, al-Jazairi. (2003).Aisiru alTafsiri Likalami al-Aliyyi al-Kabir. Madinah: Maktabah ulum wal Hikmah.

[4] Abu Jafar Muhammad bin Jarir Ath-Thabari. (2008).Jami Al Bayan an Tawil Ayi Al Quran: Tafsir Ath-Thabari, terj, Akhmad Affandi.Jakarta: Pustaka Azzam.

[5] Abuddin Nata.(2001). Filsafat Pendidikan Islam. Jakarta: Logos

[6] Ahmad Tafsir. (2003).Metodologi Pengajaran Agama Islam.Bandung: PT. Remaja Rosda Karya.

[7] Armai Arief.(2002). Pengantar Ilmu dan Metodologi Pendidikan Islam. Jakarta: Ciputat Press.

[8] Asnelly llyas. (1998).Mendambakan Anak Shaleh: Prinsip-prinsip Pendidikan Anak dalam Islam. Bandung: al-Bayan.

[9] B.F., Jones, A.S. Palincsar, D.S. , Ogle, dan E.G. Carr. (1987).Strategic teaching and learning: Cognitive instruction in the content areas.Alexandria Virginia: Association for Supervision and Curriculum Development, in cooperation with North Central Regional Educational Laboratory.

[10] J. B. Schumaker dan D.D. Deshler. (2006). "Teaching adolescents to be strategic learners," dalam J. B. Schumaker dan D.D. Deshler (ed.), Teaching adolescents with disabilities: Accessing the general education curriculum (Thousand Oaks. California: Corwin Press.

[11] Kamus Oxford-dictionari online dalam https://en.oxforddictionaries.com/definitio n/strategy, diakses tanggal 20Maret 2021.

[12] KBBI dalam http://kbbi.web.id/strategi, diakses tanggal 20Maret 2021.

[13] Kokom Komalasari. (2010).Pembelajaran Kontekstual Konsep dan Aplikasi. Bandung: Refika Aditama.

[14] Kunandar, Guru Profesional Implementasi Kurikulum Tingkat Satuan Pendidikan (KTSP) Dan Sukses Dalam Sertifikasi Guru (Jakarta : PT Raja Grafindo Persada, 2007).

[15] M. Asad. (1980).The message of Quran.Gibraltar: Dar al-Andalus Limited.

[16] M. Quraish Shihab. (2007).Secercah Cahaya ilahi: Hidup Bersama Al-Quran. Bandung: Mizan.

[17] Miftahul Huda. (2008).Interaksi Pendidikan: 10 Cara al-Quran Mendidik Anak.Malang: UIN Malang Press.

[18] Moh Usman Uzer. (2013).Menjadi Guru Profesional. Bandung : Remaja Rosda Karya.

[19] Muhammad Arifin. (1933).IImu Pendidikan Islam.Jakarta: Bumi Aksara.

[20] Oemar Hamalik. (2007).Kurikulum dan Pembelajaran. Jakarta: Bumi Aksara.

[21] Pupuh Fathurrohman dan Sobry Sutikno. (2009).Strategi Belajar Mengajar Melalui Penanaman Konsep Umum dan Konsep Islam. Bandung: PT Refika Aditama.

[22] S. Clarke. (2008).ERS focus on: Learning strategies.Alexandria, Virginia: Educational Research Service.

[23] Suyatno, Beda Strategi, Model, Pendekatan, Metode, dan Teknik Pembelajaran, http://klubguru.com, diakses 30 Maret 2021.

[24] Syaiful Bahri Djamarah dan Azwan Zain. (2014). Strategi Belajar Mengajar. Jakarta: PT Rineka Cipta. 
[25] Trianto. (2007).Model Pembelajaran Terpadu dalam Teori dan Praktek.Jakarta: Prestasi Pustaka Publisher.

[26] Triyono Supriyatno, Humanitas Spiritual dalam Pendidikan (Malang: UIN Press, 2009).

[27] Waseem Gul. (2016). "Strategy: Does the Concept Exist in Islamic Sources of Knowledge?," International Business Research; Vol. 9. No. 11.

[28] Wijārat al-Tarbiyyah wa al-Talīm. (2016).alistīrājiyyah Tațīr Tadrīs al-Qurān al-Karīm fi Madāris Tahfiż al-Qurān al-Karīm.Riyadh: Wijārat al-Tarbiyyah wa al-Talīm.

[29] Wina Sanjaya. (2007).Strategi Pembelajaran Berorientasi Standar Proses Pendidikan. Jakarta: Kencana.

[30] Zaenal Mustakim. (2012).Strategi dan Metode Pembelajaran. Pekalongan: STAIN Press.

\section{Profil Penulis 1}

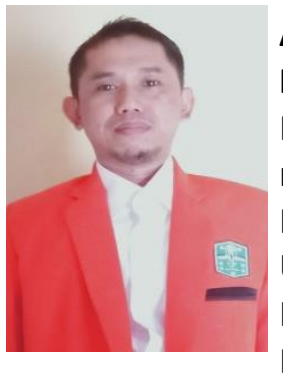

Asep Supriatna, S.Pd.I., M.Pd. Lahir di Subang, 02 Maret $\quad 1984 . \quad$ Telah menyelesaikan studi S1. Pendidikan Agama Islam di Universitas Singaperbangsa Karawang tahun 2013, serta Magister Pendidikan

Agama Islam di Institut PTIQ Jakartatahun 2017.Penulis juga sempat mondok di pesantre al-Khoir Karawang sejak tahun 2003 s.d 2010. Saat ini adalah Dosen Tetap STIT Rakeyan Santang Karawangs ejak tahun 2017-sekarang. Selain menjadi dosen penulis juga mengajar di beberapa sekolah di MTs dan SMK di lingkungan Kabupaten Karawang.

\section{Profil Penulis 2}

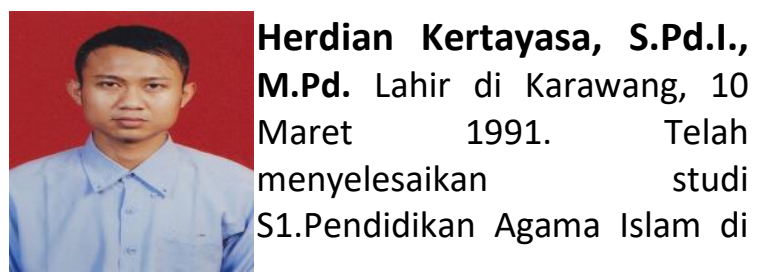

UIN Sunan Gunung Djati Bandung tahun 2013, serta

Magister Pendidikan Agama Islam UIN Sunan Gunung Djati Bandung tahun 2017. Saat ini adalah Dosen Tetap STIT Rakeyan Santang Karawang tahun 2019-sekarang. Mendalami dan mengajar matakuliah Ulumul Quran dan Hadis, Aqidah Akhlak, Metodologi Penelitian Pendidikan dan Fikih Kontemporer. Aktif menulis tentang PTK dan metodologi penelitian agama Islam.

\section{Profil Penulis3}

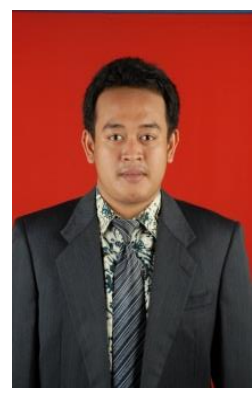

Alfyan Syach,.S.Pd.I,.M.Pd. Lahir di Karawang, 03 Februari $1987 . \quad$ Telah menyelesaikan studi pendidikan agama islam di Universitas Singaperbangsa tahun 2013, serta Magister Manajemen Pendidikan

islam di PTIQ Jakarta 2018. Saat ini adalah Dosen tetap STIT Rakeyan Santang Karawang tahun 2019-sekarang. Mendalam dan mengajar matakuliah akidah ahlak, pengamalan ibadah anak usia dini.

\section{Profil Penulis 4}

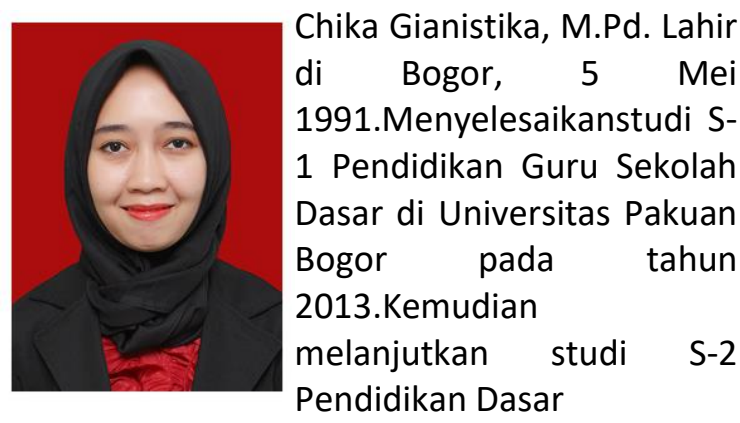

di Universitas Negeri Jakarta dan lulus pada tahun 2016. Merupakan dosen tetap STIT Rakeyan Santang Karawang tahun 2018sekarang, mengajar untuk mata kuliah keilmuan Bahasa Indonesia. Aktif menulis tentang kaidah keilmuan kebahasaan Indonesia, Sastra Indonesia pada Sekolah Dasar, serta Metode Pengajaran Bahasa Indonesia di Sekolah Dasar. 